\title{
Article \\ Molecular Pathogenesis of the Coronin Family: CORO2A Facilitates Migration and Invasion Abilities in Oral Squamous Cell Carcinoma
}

\author{
Ikuko Kase-Kato ${ }^{1, \dagger}{ }^{\dagger}$, Shunichi Asai ${ }^{2,3, \dagger}$, Chikashi Minemura ${ }^{1}$, Kenta Tsuneizumi ${ }^{1}$, Sachi Oshima ${ }^{1}$, \\ Ayaka Koma ${ }^{1}$, Atsushi Kasamatsu ${ }^{1}$ (D), Toyoyuki Hanazawa ${ }^{3}$, Katsuhiro Uzawa ${ }^{1}$ (D) and Naohiko Seki ${ }^{2, * \mathbb{D}}$ \\ 1 Department of Oral Science, Graduate School of Medicine, Chiba University, Chiba 260-8670, Japan; \\ kato.ikuko@chiba-u.jp (I.K.-K.); minemura@chiba-u.jp (C.M.); tsuneizumikenta@chiba-u.jp (K.T.); \\ Sachi.o8952@chiba-u.jp (S.O.); axna4812@chiba-u.jp (A.K.); kasamatsua@faculty.chiba-u.jp (A.K.); \\ uzawak@faculty.chiba-u.jp (K.U.) \\ 2 Department of Functional Genomics, Graduate School of Medicine, Chiba University, Chiba 260-8670, Japan; \\ cada5015@chiba-u.jp \\ 3 Department of Otorhinolaryngology/Head and Neck Surgery, Graduate School of Medicine, \\ Chiba University, Chiba 260-8670, Japan; thanazawa@faculty.chiba-u.jp \\ * Correspondence: naoseki@faculty.chiba-u.jp; Tel: +81-43-226-2971; Fax: +81-43-227-3442 \\ + These authors contributed equally to this work.
}

Citation: Kase-Kato, I.; Asai, S.; Minemura, C.; Tsuneizumi, K.; Oshima, S.; Koma, A.; Kasamatsu, A.; Hanazawa, T.; Uzawa, K.; Seki, N. Molecular Pathogenesis of the Coronin Family: CORO2A Facilitates Migration and Invasion Abilities in Oral Squamous Cell Carcinoma. Int. J Mol. Sci. 2021, 22, 12684. https:// doi.org/10.3390/ijms222312684

Academic Editors: Sven Perner and Nijiro Nohata

Received: 2 October 2021

Accepted: 22 November 2021

Published: 24 November 2021

Publisher's Note: MDPI stays neutral with regard to jurisdictional claims in published maps and institutional affiliations.

Copyright: (C) 2021 by the authors Licensee MDPI, Basel, Switzerland. This article is an open access article distributed under the terms and conditions of the Creative Commons Attribution (CC BY) license (https:// creativecommons.org/licenses/by/ $4.0 /)$

\begin{abstract}
In humans, the coronin family is composed of seven proteins containing WD-repeat domains that regulate actin-based cellular processes. Some members of the coronin family are closely associated with cancer cell migration and invasion. The Cancer Genome Atlas (TCGA) analysis revealed that $C O R O 1 C, C O R O 2 A$, and $C O R O 7$ were significantly upregulated in oral squamous cell carcinoma (OSCC) tissues ( $p<0.05$ ). Moreover, the high expression of CORO2A was significantly predictive of the 5 -year survival rate of patients with OSCC $(p=0.0203)$. Overexpression of CORO2A was detected in OSCC clinical specimens by immunostaining. siRNA-mediated knockdown of CORO2A suppressed cancer cell migration and invasion abilities. Furthermore, we investigated the involvement of microRNAs (miRNAs) in the molecular mechanism underlying CORO2A overexpression in OSCC cells. TCGA analysis confirmed that tumor-suppressive miR-125b-5p and miR-140-5p were significantly downregulated in OSCC tissues. Notably, these miRNAs bound directly to the $3^{\prime}$-UTR of CORO2A and controlled CORO2A expression in OSCC cells. In summary, we found that aberrant expression of $C O R O 2 A$ facilitates the malignant transformation of OSCC cells, and that downregulation of tumor-suppressive miRNAs is involved in CORO2A overexpression. Elucidation of the interaction between genes and miRNAs will help reveal the molecular pathogenesis of OSCC.
\end{abstract}

Keywords: oral squamous cell carcinoma; coronin; CORO2A; microRNA; miR-125b-5p; miR-140-5p

\section{Introduction}

Oral squamous cell carcinoma (OSCC), which originates from oral keratinocytes in the oral cavity, accounts for $40 \%$ of head and neck squamous cell carcinomas (HNSCCs) [1]. According to Global Cancer Statistics 2018, there were approximately 350,000 new cases with OSCC and 180,000 deaths from the disease per year worldwide [2]. Most OSCC cases are detected at an advanced stage, and the 5-year survival rate of patients with advanced OSCC is approximately 50\% [3]. Advanced-stage patients are treated with combination therapies, such as surgery, radiation, chemotherapy, and immunotherapy [4]. However, OSCC cells acquire resistance to these treatments, resulting in local recurrence and distant metastasis [5]. Unfortunately, there is no effective treatment for patients who have acquired treatment resistance [6]. Elucidation of the molecular mechanisms of acquiring treatment resistance and subsequent development of distant metastasis is indispensable for the development of new treatments for OSCC. 
Metastasis is the process by which cancer cells migrate to distant sites via the lymphatic system or bloodstream to form colonies, and it is an important event determining the prognosis of patients [7]. Various molecules play roles in the metastatic process in a complex manner. Cancer cells induce changes in cell adhesion and degradation of surrounding cells and acquire the ability to migrate within tissues and metastasize [8]. The dynamic involvement of actin is required for cancer cells to alter their morphology and promote migration and invasion [9]. At the edge of migrating and invading cells, actin polymerization is controlled by various actin regulators, e.g., Rho GTPases, WASP and WAVE proteins, and actin-related proteins [10].

The coronin family comprises WD-repeat proteins, which are expressed in a large number of eukaryotic organisms [11]. The WD domain is thought to function as a stable platform for interacting with other proteins [12]. As the typical structure of a coronin protein, it contains three to five WD-repeat clusters forming the central core domain, as well as a coiled-coil domain in the carboxy terminus [13]. In humans, seven coronin genes have been identified: CORO1A (coronin 1), CORO1B (coronin 2), CORO1C (coronin 3), CORO2A (coronin 4), CORO2B (coronin 5), CLIPINE (coronin 6), and POD1 (coronin 7) [14].

Previous studies showed that coronins are associated with the actin-related protein $2 / 3$ complex and are involved in an F-actin rearrangement, suggesting that coronins act as actin-binding proteins [15]. Overexpression of CORO1C in cancer cells has been reported in a wide range of cancers, and its overexpression contributes to cancer cell migration and invasion [16]. In this study, we investigated the clinical significance of human coronins using The Cancer Genome Atlas (TCGA) database. Analysis of the TCGA-HNSC database showed that expression of CORO2A was upregulated in HNSCC tissues, and its high expression significantly predicted the 5 -year survival rate of patients with HNSCC.

A large number of studies have shown that microRNAs (miRNAs) act as pivotal controllers of gene expression [17]. miRNAs, short single-stranded molecules, negatively control gene expression in normal and diseased cells in a sequence-dependent manner $[18,19]$. In cancer cells, a vast number of studies have demonstrated that downregulation of tumorsuppressive miRNAs caused overexpression of oncogenes, and these events facilitated cancer cell aggressiveness, e.g., proliferation, metastasis, and drug resistance [20,21].

The study aimed to investigate the oncogenic function of CORO2A and to clarify the involvement of miRNAs that control CORO2A expression in OSCC cells.

\section{Results}

2.1. Expression and Clinical Significance of the Coronin Family in Patients with OSCC According to TCGA Database Analysis

Expression levels of the coronin family members (CORO1A, CORO1B, CORO1C, CORO2A, CORO2B, CORO6, and CORO7) were evaluated using the TCGA database (TCGA-OSCC). The expression levels of three coronin genes (CORO1C, CORO2A, and CORO7) were significantly upregulated in OSCC tissues $(n=313)$ compared with normal tissues $(n=30)$ (Figure 1$)$. On the other hand, the expression of CORO2B was significantly downregulated in OSCC tissues (Figure 1). There was no significant difference in the expression levels of the other three genes (CORO1A, CORO1B, and CORO6) between OSCC and normal tissues (Figure 1). 

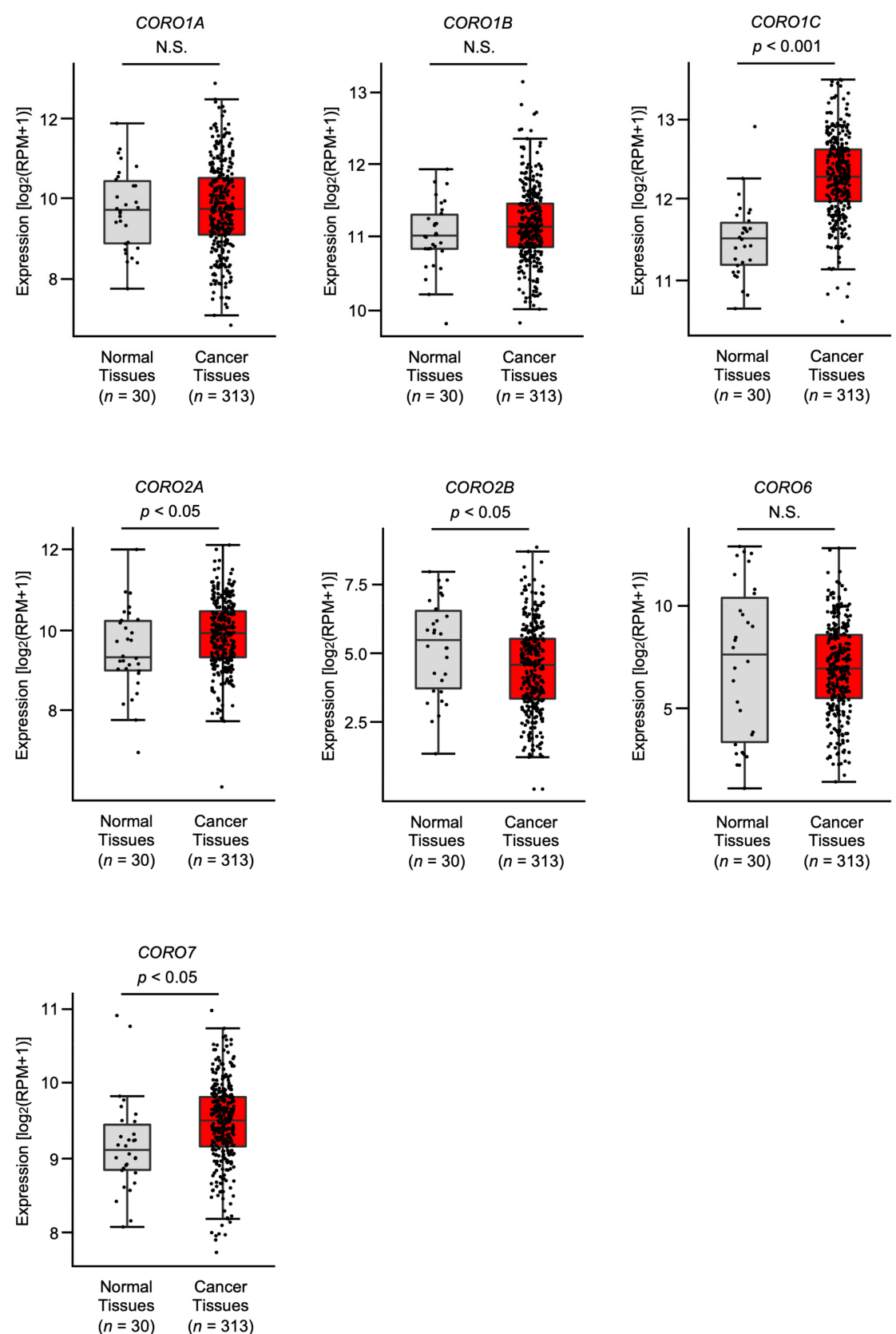

Figure 1. Expression of all members of coronin family by TCGA-OSCC analysis. Expression levels of CORO1A, CORO1B, CORO1C, CORO2A, CORO2B, CORO6, and CORO7 in OSCC tissues. A total of 313 OSCC tissues and 30 normal epithelium tissues were analyzed (N.S., not significant).

To determine the clinical effectiveness, a clinicopathological analysis of the coronin family was performed using TCGA-OSCC data. Patients with high expression of CORO1B and $C O R O 2 A$ had a significantly worse prognosis compared with those with low expression (Figure 2A and Table S1). Multivariate Cox regression analysis was performed about expression levels of $C O R O 1 B$ and $C O R O 2 A$ with other expected prognostic factors (age, disease stage, and pathological grade). As result, CORO2A expression levels were independent prognostic factors (Figure 2B). 
A
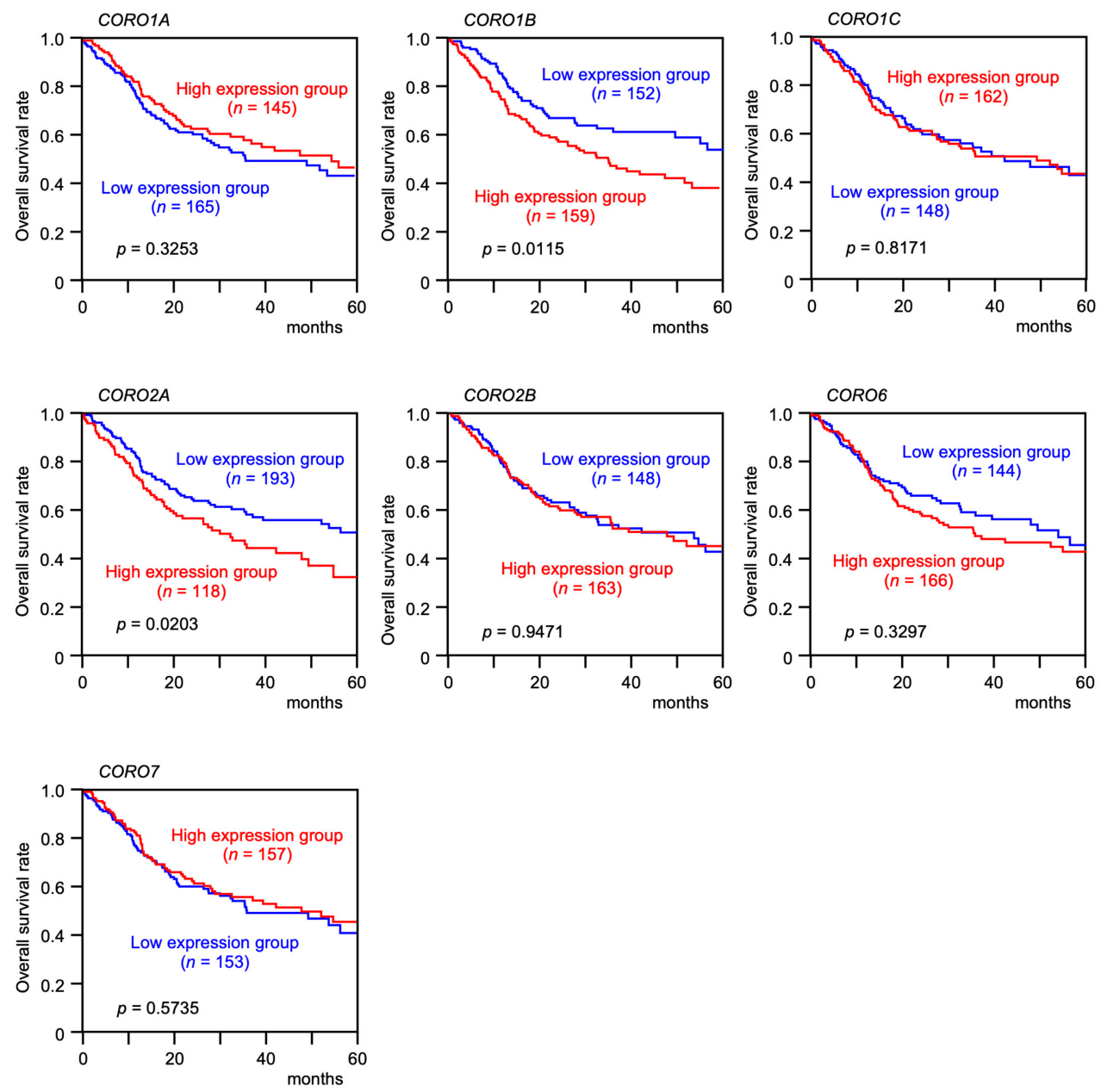

B

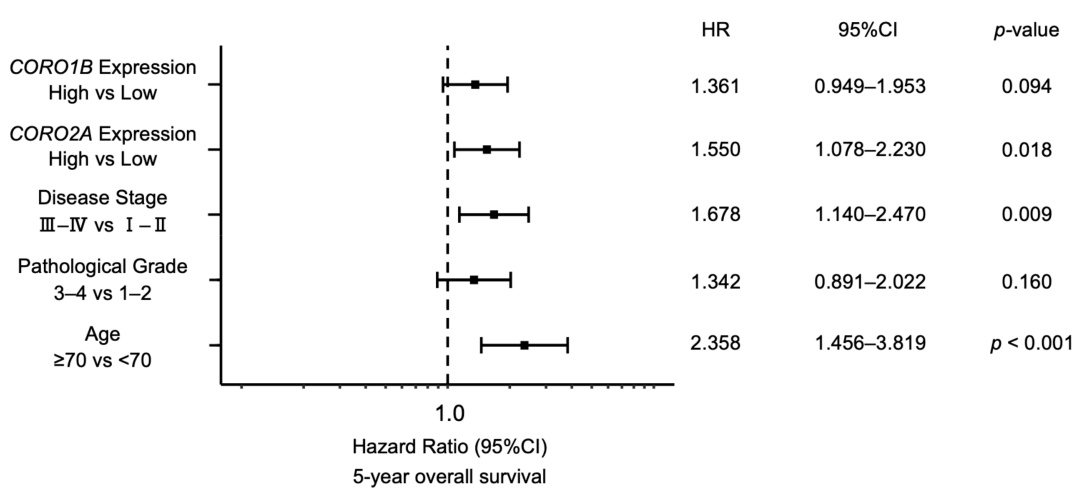

Figure 2. Clinical significance of all members of the coronin family by TCGA-OSCC analysis. (A) Kaplan-Meier survival curve analyses of patients with OSCC using data from The Cancer Genome Atlas (TCGA) database. Patients were divided into high and low expression groups according to miRNA expression (based upon median expression). The red line shows the high expression group, and the blue line shows the low expression group. (B) Forest plot presenting the results of a multivariate Cox regression analysis of the prognostic value of CORO1B and CORO2A identified in an OSCC dataset from TCGA (HR: hazard ratio, CI: confidence interval). The expression level of CORO2A was determined to be independent prognostic factors in terms of the 5 -year overall survival rate after adjustments for tumor stage, age, and pathological grade $(p<0.05)$. 
Based on the results of these analyses, CORO2A was selected among the coronin family members for the functional analyses.

\subsection{Overexpression of CORO2A in OSCC Clinical Specimens}

Expression of the CORO2A protein was investigated by immunostaining in OSCC clinical specimens. Aberrant expression of CORO2A was detected in OSCC lesions (Figure 3). In contrast, there was almost no CORO2A expression in the normal epithelium (Figure 3). Clinical features of 4 OSCC cases used for immunohistochemical staining were summarized in Table S2.

A

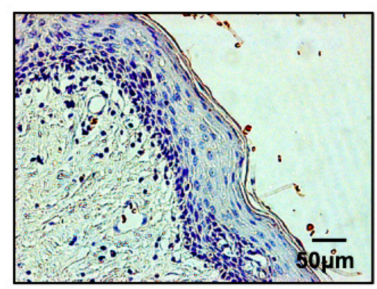

B

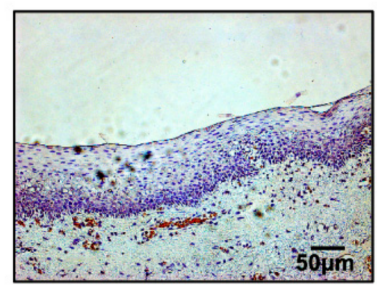

C

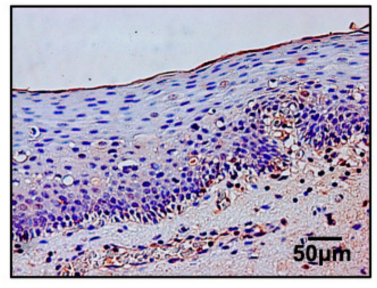

D

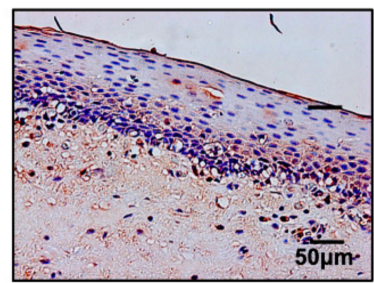

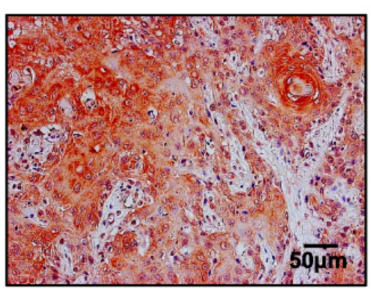
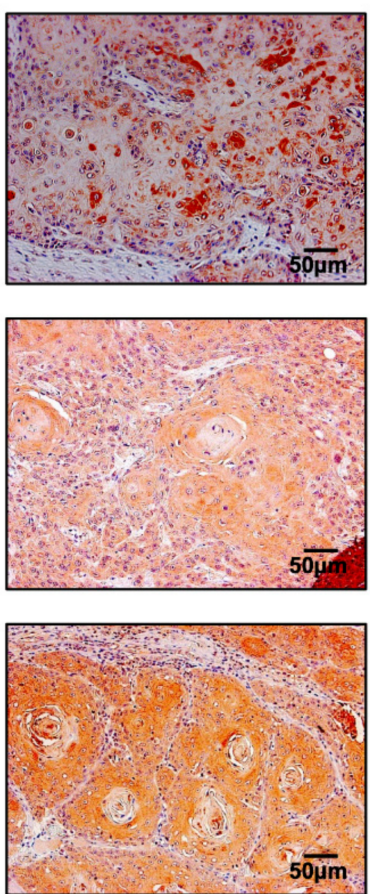
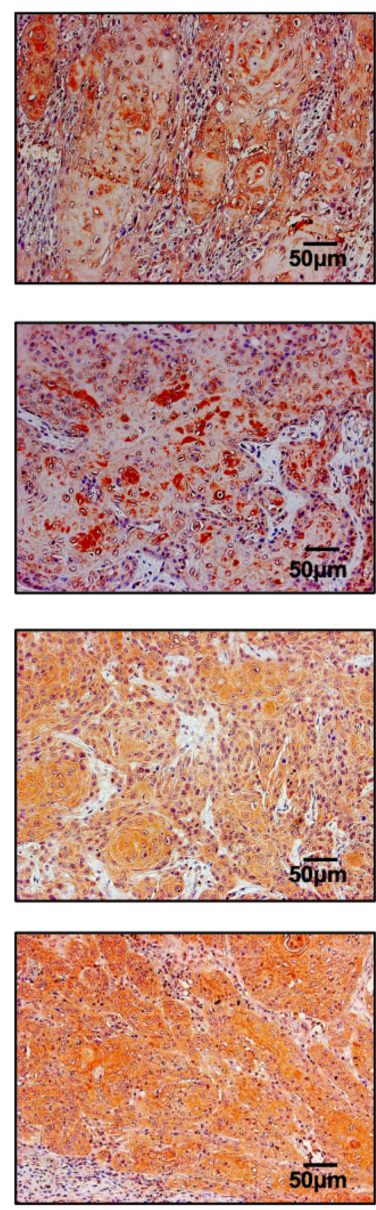

$\times 200$

Figure 3. Overexpression of CORO2A in OSCC clinical specimens. Immunohistochemical staining of CORO2A in OSCC clinical specimens. High expression of CORO2A was detected in the nuclei and/or cytoplasm of cancer cells ((A-D) center and right side) and weak expression in the normal oral mucosa ((A-D) left side).

\subsection{Effects of CORO2A Knockdown on the Proliferation, Invasion, and Migration of OSCC Cells}

To assess the oncogenic function of CORO2A in OSCC cells, we performed knockdown assays using small interfering RNAs (siRNAs). Prior to this experiment, we evaluated the expression of CORO2A in OSCC cells lines (HSC-2, HSC-3, SAS, Sa3, Ca9-22, and Ho-N-1), and found that CORO2A expression was detected in all of these cell lines (Figure 4). On the other hand, its expression in normal fibroblast lines (IMR-90 and MRC-5) was weaker compared with the OSCC cell lines (Figure 4). 


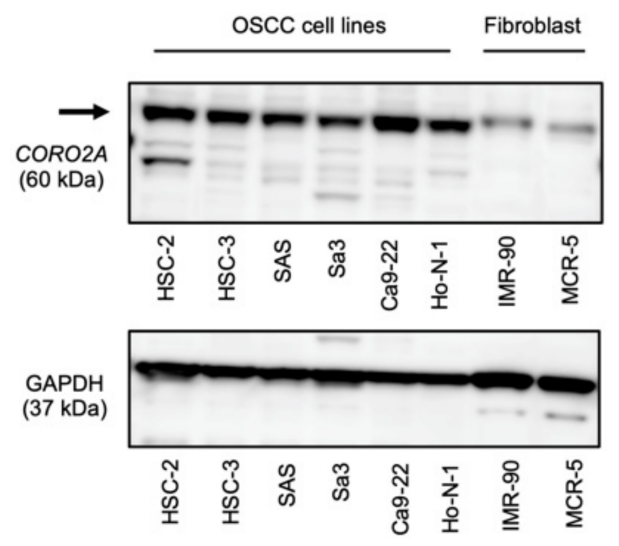

Figure 4. Expression levels of CORO2A in the OSCC cell lines. Expression levels of CORO2A in OSCC cell lines and normal fibroblast cell lines were evaluated with Western blotting. GAPDH was used as the internal control.

Next, the inhibitory effect of two different siRNAs targeting CORO2A (siCORO2A-1 and siCORO2A-2) on CORO2A expression was examined. The CORO2A mRNA and protein levels were effectively suppressed by transfection of both siRNAs into SAS and HSC-3 cells (Figure 5A,B).

A
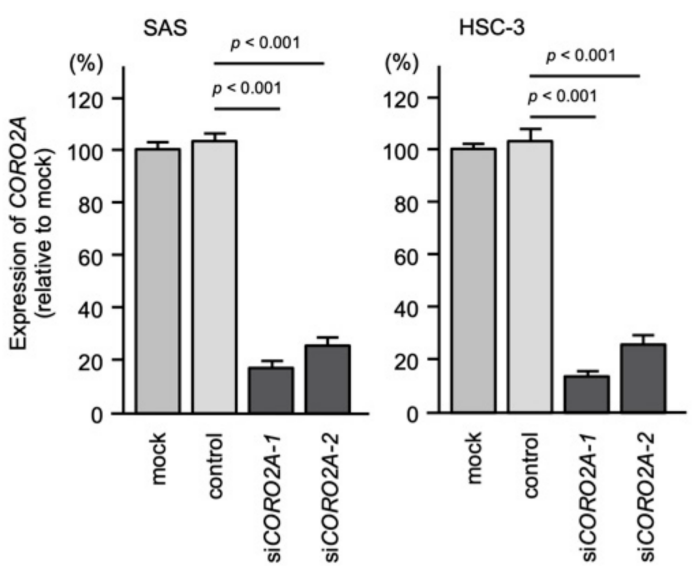

B
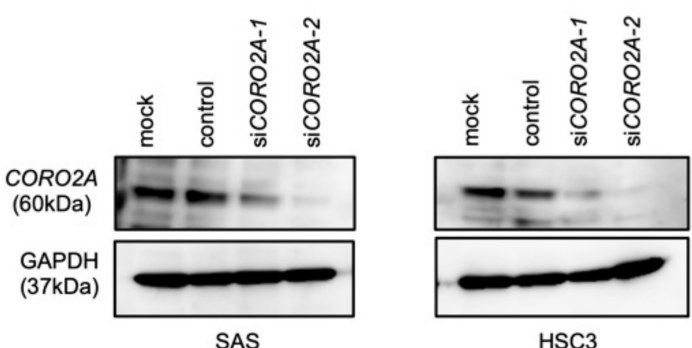

Figure 5. Knockdown efficiencies of siRNAs in OSCC cell lines (SAS and HSC-3 cells). Knockdown efficiencies of CORO2A expression by siCORO2A-1 and siCORO2A-2 were evaluated by real-time PCR (A) and Western blotting (B). Data of expression of CORO2A (mRNA) and CORO2A (protein) were collected $72 \mathrm{~h}$ after siRNAs transfection. GAPDH (mRNA) and GAPDH (protein) were used as internal controls.

Knockdown of CORO2A had a slight inhibitory effect on cell proliferation in SAS and HSC-3 cells (Figure 6A), and the cell invasion and migration abilities were significantly inhibited after siCORO2A transfection in SAS and HSC-3 cells (Figures 4B,C, S1 and S2). 
A


B
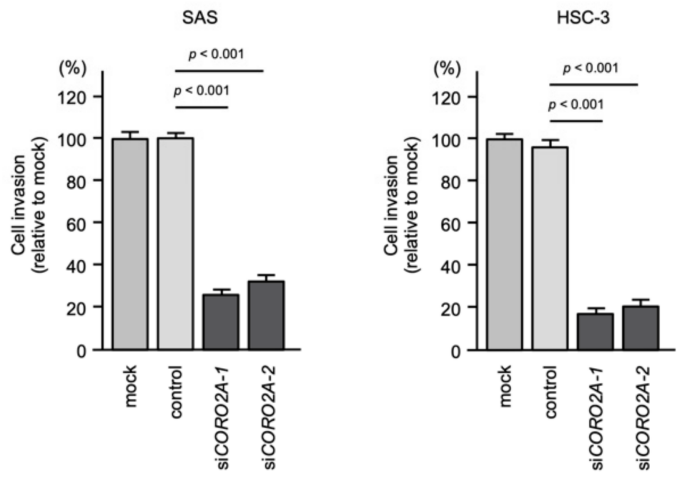

C


Figure 6. Functional assays of cell proliferation, migration, and invasion following transient transfection of siRNAs in OSCC cell lines (SAS and HSC-3 cells). (A) Cell proliferation was assessed using XTT assays. Data were collected $96 \mathrm{~h}$ after siRNAs transfection. (B) Cell invasion was determined $48 \mathrm{~h}$ after seeding miRNA-transfected cells into chambers using Matrigel invasion assays. (C) Cell migration was assessed with a wound-healing assay. Data were collected $0 \mathrm{~h}, 12 \mathrm{~h}$, and $24 \mathrm{~h}$ after cell scratch.

\subsection{Selection of miRNAs That Regulate CORO2A Expression in OSCC Cells}

Downregulation of some miRNAs is associated with overexpression of CORO2A in OSCC cells. We searched for miRNAs that negatively regulate CORO2A expression in OSCC cells. The strategy for identifying miRNAs that regulate CORO2A expression is shown in Figure 7A. An analysis of the TargetScan database (release 7.2) combined with our miRNA expression signature of OSCC (accession number: GSE184991) revealed that three miRNAs (miR-125a-5p, miR-125b-5p, and miR-140-5p) regulate CORO2A expression in OSCC cells (Figure 7B). TCGA database analysis showed that the expression levels of miR$125 b-5 p$ and miR-140-5p were significantly reduced in OSCC tissues $(n=297)$ compared with normal tissues $(n=30)$ (Figure 7C). Based on these results, we investigated the regulation of CORO2A expression by miR-125b-5p and miR-140-5p. 
A

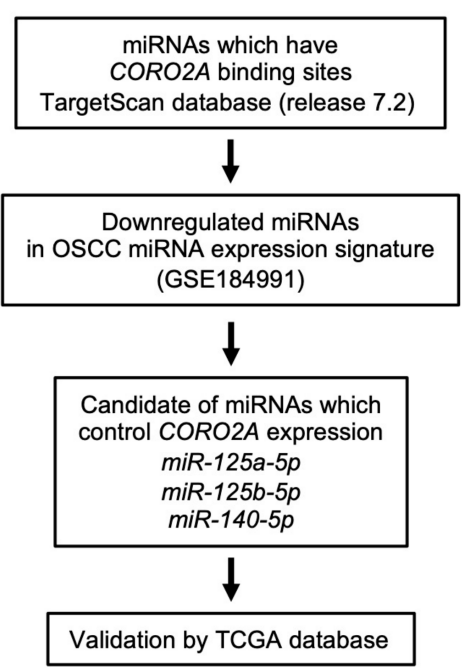

B

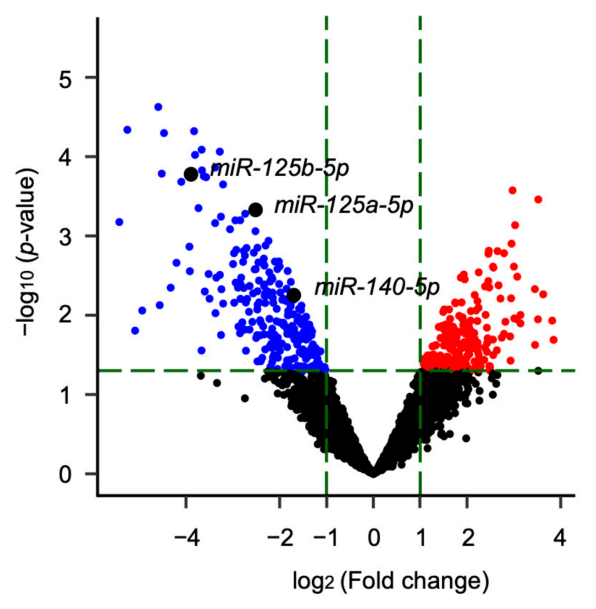

(C)
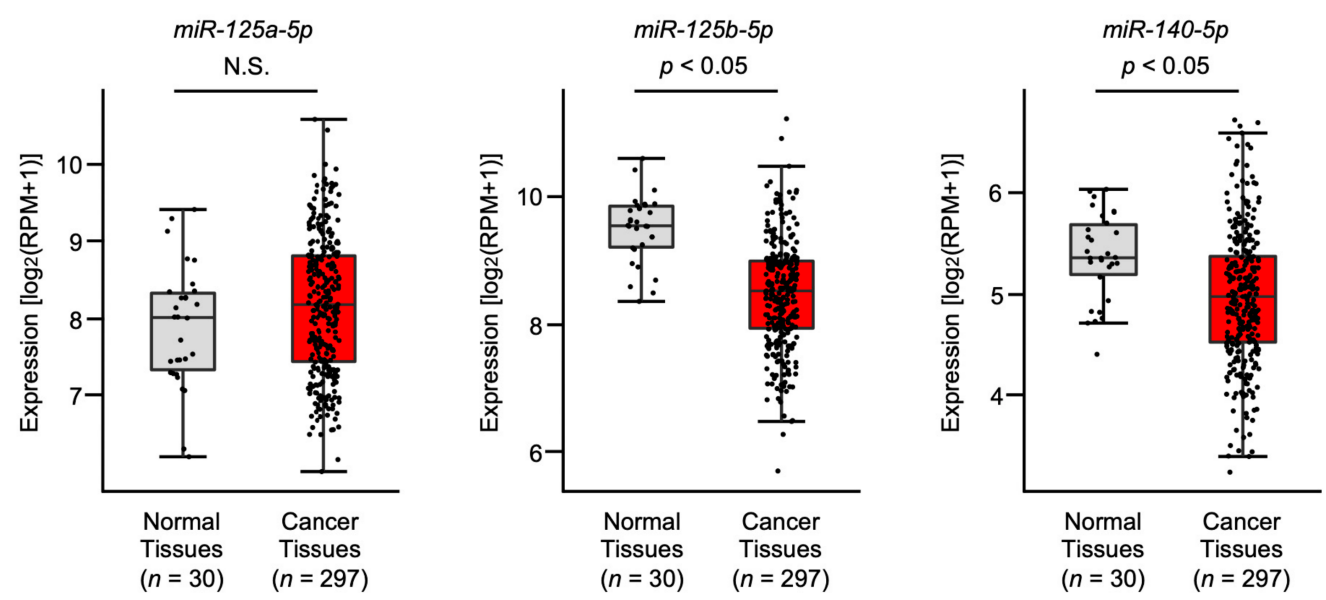

Figure 7. Selection of CORO2A controlled miRNAs in OSCC cells. To identify miRNAs controlling CORO2A expression in OSCC cells, we used the TargetScan database (release 7.2) and the miRNA expression signature of OSCC. (A) Flowchart of the strategy used to identify the candidate of CORO2A regulated miRNAs in OSCC cells. (B) Volcano plot of the miRNA expression signature determined through RNA sequencing. The $\log _{2}$ fold change (FC) is plotted on the $x$-axis, and the $\log _{10}$ ( $p$-value) is plotted on the $\mathrm{y}$-axis. The blue points represent the downregulated miRNAs with an absolute $\log _{2} \mathrm{FC}<-1.0$ and $p<0.05$. (C) The expression levels of miR-125a-5p, miR-125b-5p, and miR-140-5p evaluated in an HNSCC dataset from TCGA (N.S., not significant).

\subsection{Regulation of CORO2A Expression by miR-125b-5p and miR-140-5p in OSCC Cells}

Both the mRNA and protein levels of CORO2A were reduced by miR-125b-5p transfection in SAS and HSC-3 cells (Figure 8A,B). To investigate whether $m i R-125 b$ - $5 p$ binds directly to CORO2A in OSCC cells, we conducted a dual-luciferase reporter assay. Luciferase activity was significantly reduced following co-transfection with miR-125b-5p and a vector containing the miR-125b-5p-binding site of CORO2A. On the other hand, co-transfection with a vector lacking the $m i R-125 b-5 p$-binding site of CORO2A resulted in no change in luciferase activity (Figure $8 \mathrm{C}$ ).

Both the mRNA and protein levels of CORO2A were reduced by miR-140-5p transfection in SAS and HSC-3 cells (Figure 9A,B). A dual-luciferase reporter assay showed that luciferase activity was significantly reduced following co-transfection with $m i R-140-5 p$ and a vector containing the miR-140-5p-binding site of CORO2A. There was no change in luciferase activity following co-transfection with $m i R-140-5 p$ and a vector lacking the miR-140-5p-binding site (Figure 9C). 

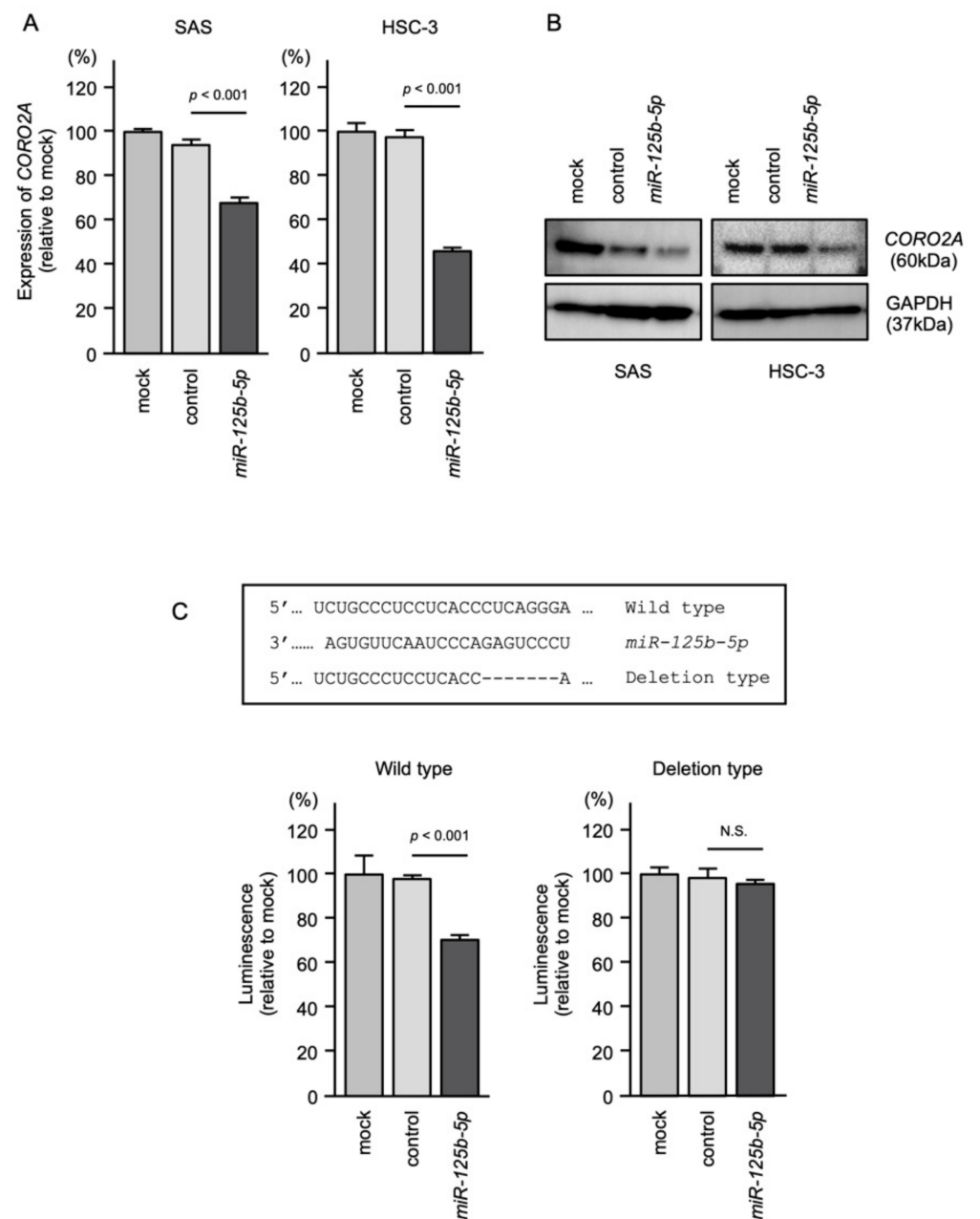

Figure 8. Direct regulation of CORO2A expression by $m i R-125 b-5 p$ in OSCC cells. (A) Real-time PCR showing the significantly reduced expression of CORO2A mRNA at $48 \mathrm{~h}$ after $m i R-125 b-5 p$ transfection in SAS and HSC-3 cells. Expression of GAPDH was used as an internal control. (B) Western blot showing reduced expression of the CORO2A protein at $48 \mathrm{~h}$ after miR-125b-5p transfection in SAS and HSC-3 cells. Expression of GAPDH was used as an internal control. (C) TargetScan database shows that a single putative miR-125b-5p binding site predicts the $3^{\prime} \mathrm{UTR}$ of CORO2A sequence (upper panel). Dual-luciferase reporter assays showed reduced luminescence activity after co-transfection of the wild-type vector and miR-125b-5p in HSC-3 cells (lower panel). Normalized data were calculated as the Renilla/firefly luciferase activity ratio (N.S., not significant).
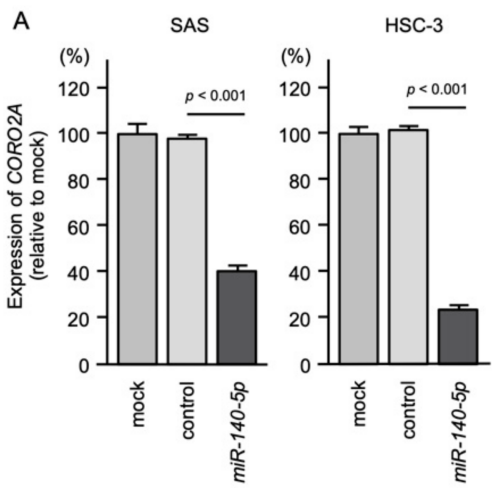

B

Figure 9. Cont. 
C
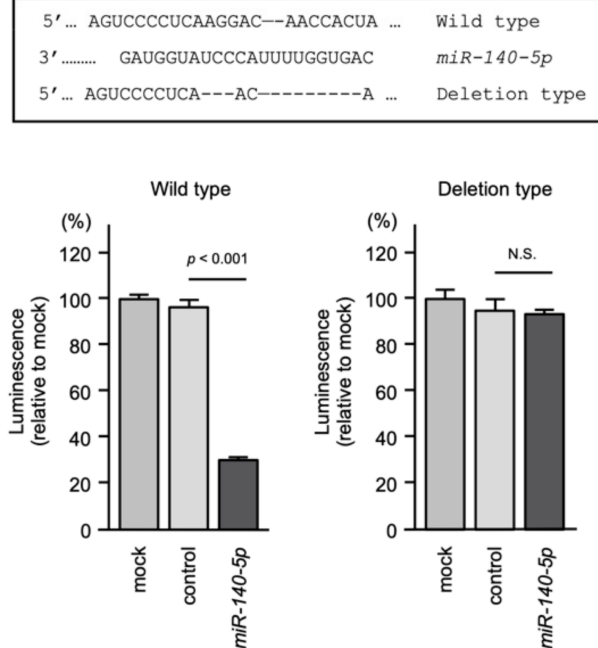

Figure 9. Direct regulation of CORO2A expression by miR-140-5p in OSCC cells. (A) Real-time PCR showing the significantly reduced expression of CORO2A mRNA at $48 \mathrm{~h}$ after miR-140-5p transfection in SAS and HSC-3 cells. Expression of GAPDH was used as an internal control. (B) Western blot showing reduced expression of the CORO2A protein at $48 \mathrm{~h}$ after miR-140-5p transfection in SAS and HSC-3 cells. Expression of GAPDH was used as an internal control. (C) TargetScan database shows that a single putative miR-140-5 $p$ binding site predicts the $3^{\prime}$ UTR of CORO2A sequence (upper panel). Dual-luciferase reporter assays showed reduced luminescence activity after co-transfection of the wild-type vector and $m i R-140-5 p$ in HSC-3 cells (lower panel). Normalized data were calculated as the Renilla/firefly luciferase activity ratio (N.S., not significant).

These findings suggest that $m i R-125 b-5 p$ and $m i R-140-5 p$ directly regulate CORO2A expression in OSCC cells.

\subsection{Effects of Ectopic Expression of miR-125b-5p and miR-140-5p in OSCC Cells}

The tumor-suppressive activities of $m i R-125 b-5 p$ and $m i R-140-5 p$ were assessed by ectopic expression of mature miRNAs in SAS and HSC-3 cells. The results showed that cell proliferation was suppressed by miR-125b-5p transfection in OSCC cells (Figure 10A). Especially, cancer cell invasion and migration abilities were markedly suppressed by the expression of miR-125b-5p in OSCC cells (Figures 10B,C, S3 and S4.)

(A)
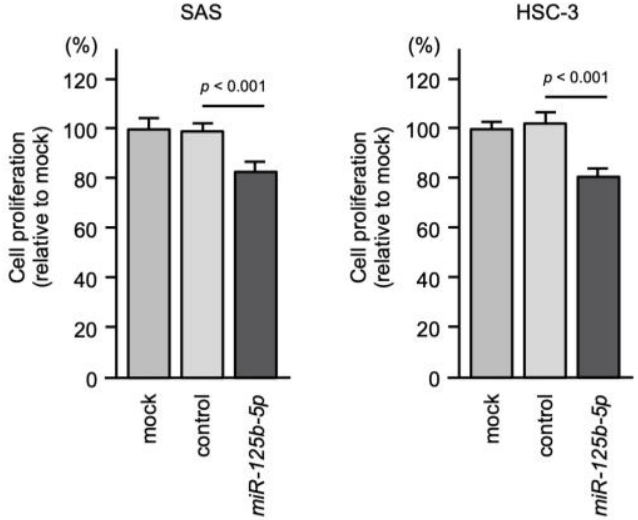

Figure 10. Cont. 
(B)
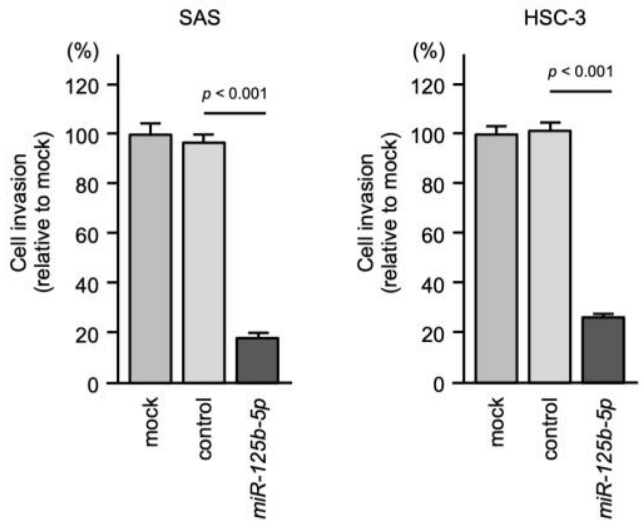

(C)

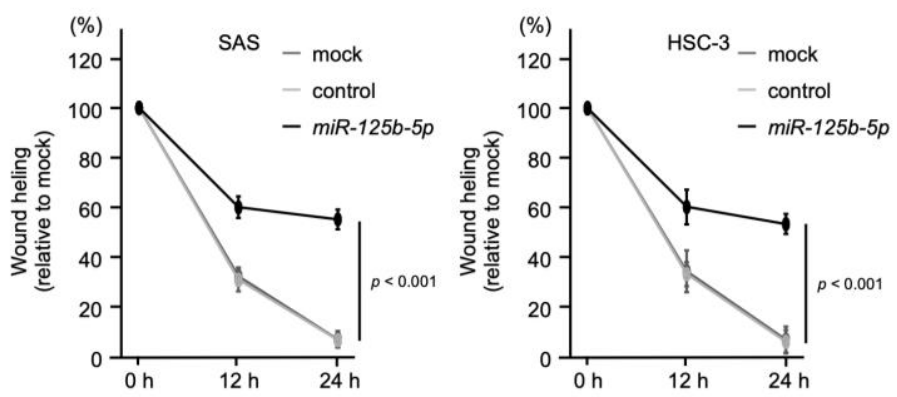

Figure 10. Tumor-suppressive function of $m i R-125 b-5 p$ in OSCC cells. (A) Cell proliferation assessed with an XTT assay at $72 \mathrm{~h}$ after transfection of mature miRNAs. (B) Cell invasion determined with a Matrigel invasion assay at $48 \mathrm{~h}$ after seeding miRNA-transfected cells into the chambers. (C) Cell migration was assessed with a wound-healing assay. Data were collected $0 \mathrm{~h}, 12 \mathrm{~h}$, and $24 \mathrm{~h}$ after cell scratch.

Similar to miR-125b-5p, ectopic expression of miR-140-5p attenuated OSCC cell aggressiveness, i.e., cell proliferation, invasion, and migration abilities (Figure $11 \mathrm{~A}-\mathrm{C}$ ). These findings suggest that $m i R-125 b-5 p$ and $m i R-140-5 p$ act as tumor-suppressive miRNAs in OSCC cells. (Figures S5 and S6).

(A)
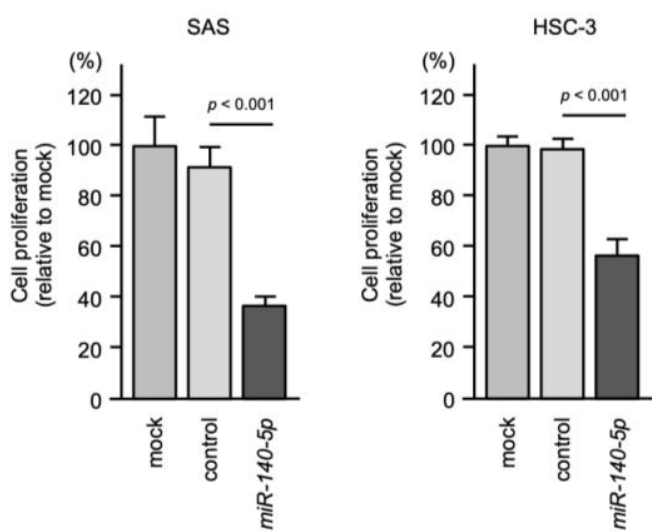

Figure 11. Cont. 

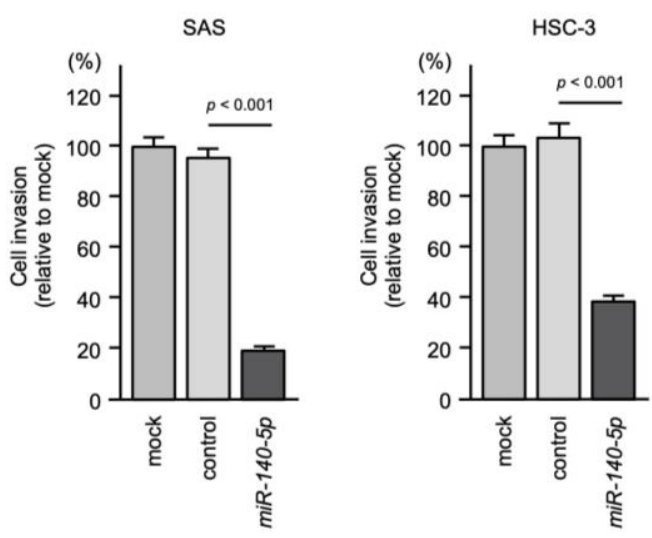

(C)
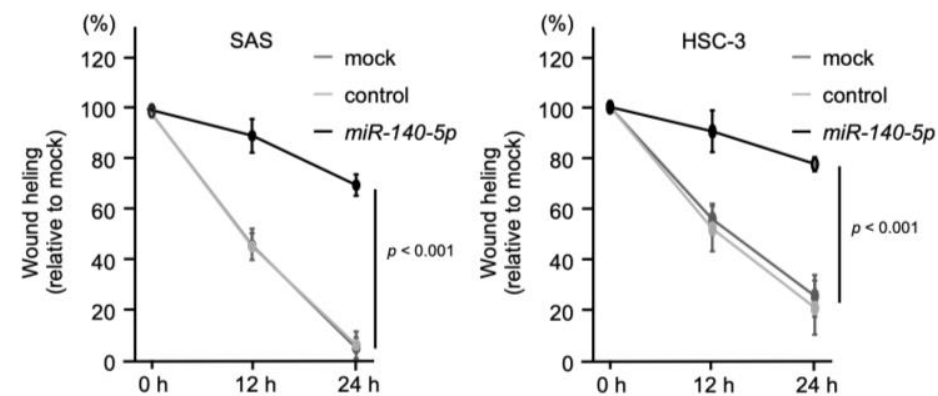

Figure 11. Tumor-suppressive function of $m i R-140-5 p$ in OSCC cells. (A) Cell proliferation assessed with an XTT assay at $72 \mathrm{~h}$ after transfection of mature miRNAs. (B) Cell invasion determined with a Matrigel invasion assay at $48 \mathrm{~h}$ after seeding miRNA-transfected cells into the chambers. (C) Cell migration was assessed with a wound-healing assay. Data were collected $0 \mathrm{~h}, 12 \mathrm{~h}$, and $24 \mathrm{~h}$ after cell scratch.

\section{Discussion}

The prognosis of patients with OSCC depends largely on the presence or absence of metastasis. Metastasis (regional lymph node or distant metastasis) is a major cause of death in patients with OSCC, and the 5-year survival rate of OSCC patients with metastasis is less than $40 \%$ [22]. Searching for molecular networks involved in metastasis is an essential challenge in improving the prognosis of patients with OSCC.

Cancer cells acquire cell motility via regulation of the cytoskeletal structure, allowing them to move travel from the primary tumor site to distant tissues [23]. Cancer cells control F-actin filaments at the leading edge to form various protrusion processes, e.g., lamellipodia, filopodia, and invadopodia [24]. Various actin-related proteins (e.g., Arp2/3, WASP/WAVE, fascin, and tropomyosins) are involved in the formation of these protrusions in a complex manner [25-27]. For instance, cortactin (CTTN) has multiple binding domains that can bind several proteins, e.g., Arp2/3 complex, F-actin, WASL, WIPE-1, and Src [28]. Overexpression of CTTN was reported by several cancers, including OSCC, and its expression enhanced cancer cell aggressiveness in OSCC [29,30]. Moreover, aberrant expression of CNNT significantly predicted the HNSCC prognosis [31].

Coronins are actin-binding proteins containing WD repeats that are evolutionarily conserved from invertebrates to vertebrates [13]. In humans, the coronin family comprises at least seven genes [14]. Among these, CORO1C contributes to invadopodium formation via the F-actin and Arp2/3 complex [32]. Overexpression of CORO1C has been reported in various solid tumors, including glioblastoma, hepatocellular, breast, lung, gastric, and colorectal cancers [32-37]. In colorectal cancer, high expression of CORO1C is associated with malignant phenotypes, such as lymph node and distant metastases. Moreover, the oncogenic PI3K/AKT signaling pathway was suppressed by the knockdown 
of CORO1C [38]. In gastric cancer, the knockdown of CORO1C markedly suppressed the malignant transformation of cancer cells [37].

CORO2A is a component of the nuclear receptor co-repressor complex involved in the actin-dependent activation of inflammatory response genes [39]. There have not been many reports on CORO2A expression in human cancers. A previous study showed elevated expression of $\mathrm{CORO} 2 \mathrm{~A}$ in colorectal carcinoma tissues, and a link between its expression and oncogenic MAPK14 and PRMT5 signaling pathways [40]. A recent study showed that expression of $C O R O 2 A$ was associated with overall survival and relapse-free survival in patients with triple-negative breast cancer; moreover, knockdown of CORO2A reduced malignant transformation and induced cell cycle arrest [41]. The results of that study are consistent with our results in OSCC showing that CORO2A expression is a potential predictor of OSCC prognosis. Furthermore, controlling CORO2A expression and CORO2Amediated oncogenic pathways may provide promising therapeutic strategies for OSCC treatment. A large number of cohort studies by other institutions are essential for CORO2A expression to gain clinical significance in OSCC.

In this study, we investigated the molecular mechanisms underlying the aberrant expression of CORO2A in oral cancer, focusing on miRNAs. A vast number of studies demonstrated that miRNAs act as fine-tuners of gene expression in a sequence-dependent manner $[18,19]$. Tumor-suppressive miRNAs are frequently downregulated, whereas their oncogene targets are upregulated, in cancer cells. A previous analysis of our RNA-sequencing-based miRNA signature of OSCC revealed that $m i R-125 b-5 p$ and $m i R-140-5 p$ were downregulated in cancer tissues [42]. Our present study showed that these miRNAs have tumor-suppressive roles, and $m i R-125 b-5 p$ and miR-140-5p directly regulate the expression of CORO2A in OSCC cells.

Downregulation and antitumor roles of $m i R-125 b-5 p$ have been reported in several types of cancers [43-48]. For instance, $m i R-125 b-5 p$ is downregulated in esophageal squamous cell carcinoma, and ectopic expression assays demonstrated that its expression attenuated cancer cell aggressiveness via regulation of cell cycle regulatory genes and epithelial-mesenchymal transition (EMT)-related genes [49]. In laryngeal squamous cell carcinoma cells, ectopic expression of $m i R-125 b-5 p$ blocked glucose consumption by targeting hexokinase-2 [46].

Previous studies have reported downregulation of miR-140-5p in several cancer types [50-54]. In hypopharyngeal squamous cell carcinoma, expression of miR-140-5p suppressed cancer cell migration and invasion abilities by regulating ADAM10-mediated Notch1 signaling. Moreover, downregulation of miR-140-5p was associated with tumor classification and lymph node metastasis [55]. In OSCC cells, overexpression of the long noncoding RNA HCP5 promoted cancer cell proliferation and EMT by adsorbing miR-140-5p . Notably, suppression of miR-140-5p expression alleviated repression of SOX4, a master regulator of EMT in OSCC cells [56].

The finding that the antitumor miRNAs miR-125b-5p and $m i R-140-5 p$ are involved in the regulation of CORO2A expression in OSCC cells is interesting and new. Detailed functional analyses of $C O R O 2 A$ and its regulated antitumor miRNAs will provide important information for elucidating the molecular pathogenesis of OSCC.

In this study, we focused on CORO2A among the coronin family and analyzed its oncogenic functions and epigenetic modification in OSCC cells. For other coronin families that have not been analyzed in this study (especially, CORO1C, CORO2B, and CORO7 whose expressions are dysregulated in cancer tissues), it is essential to elucidate the molecular pathogenesis of OSCC. Continued analysis of these genes may reveal therapeutic targets for OSCC.

\section{Materials and Methods}

\subsection{Human OSCC Cell Lines}

The six OSCC-derived cell lines (HSC-2, HSC-3, SAS, Sa3, Ca9-22, and HO-1-N-1) and two human fibroblast lines (IMR-90 and MRC-5) were used in this study (Table S3). These cell lines were obtained from the RIKEN BioResource Center (Tukuba, Ibaraki, Japan). 


\subsection{RNA Extraction and $q R T-P C R$}

RNA was extracted from cell lines and subjected to this study as described previously $[42,57,58]$. The TaqMan probes and primers used in this study are listed in Table S4.

\subsection{Transfection of siRNAs and miRNAs into HNSCC Cells}

Transfection of siRNAs and miRNAs into OSCC cell lines was performed using Lipofectamine RNAiMAX reagent (Invitrogen, Carlsbad, CA, USA) according to our previous studies $[42,57,58]$. The reagents used in this study are listed in Table S4.

\subsection{Functional Assays (Cell Proliferation, Migration, and Invasion Assays) in HNSCC Cells}

The XTT assay for cell proliferation and the Matrigel chamber assay for the invasion were performed in OSCC cells as described previously $[42,57,58]$. In the wound healing assay for migration, a wound was created using a micropipette tip in the middle of each plate after siRNA or pre-miRNAs transfection $48 \mathrm{~h}$. We incubated plates at $37{ }^{\circ} \mathrm{C}$ at $5 \%$ carbon dioxide with a free-serum medium, and live-cell migration was captured after 12 and $24 \mathrm{~h}$.

\subsection{Clinical Significance of CORO2A in OSCC Patients Based on TCGA-HNSC Data}

Gene expression analysis for each gene were obtained from OncoLnc (http:/ / www. oncolnc.org, accessed on 20 April 2021) [59]. For the Kaplan-Meier plot, log-rank test, and Cox proportional hazards regression test, we used TCGA-HNSC clinical data (TCGA, Firehose Legacy) obtained from cBioportal (https://www.cbioportal.org, accessed on 10 April 2020). Among TCGA-HNSC, those whose primary site was in the oral cavity (alveolar ridge, buccal mucosa, floor of mouth, hard palate, lip, and oral tongue) were narrowed down as TCGA-OSCC. The clinical features of TCGA-OSCC $(n=343)$ was shown in Table S5. In multivariate analysis, gene expression levels, tumor stage, pathological grade, and age at diagnosis were used as covariates.

For these analyses, we used JMP Pro 15.0.0 (SAS Institute Inc., Cary, NC, USA).

\subsection{Identification of CORO2A Expression Controlled miRNAs}

The strategy used to identify CORO2A target miRNAs is presented in Figure 7. We selected putative miRNA target sites within the CORO2A sequence using TargetScanHuman ver. 7.2 (http:/ / www.targetscan.org/vert_72/, accessed on 10 July 2020) [60]. The expression signature of OSCC miRNA was used for screening. Our OSCC miRNA signature was deposited in the GEO database (accession number: GSE184991). Clinical features of 3 OSCC cases used for miRNA sequence were summarized in Table S6.

\subsection{Western Blotting and Immunohistochemistry}

The procedure of Western blotting and immunohistochemistry were described as previously $[42,57,58]$. The antibodies used in this study are shown in Table S4. Full blots of the membrane are shown in Figures S7-S10

\subsection{Clinical Specimens}

The clinical information of the patients using immunostaining are shown in Table S2. Our study has been approved by the Ethics Committee of Chiba University (approval number; 28-65, 10 February 2015). The research methodology is implemented in accordance with the standards set by the Declaration of Helsinki.

\subsection{Plasmid Construction and Dual-Luciferase Reporter Assays}

Plasmid vectors containing CORO2A with the wild-type sequences of the miRNAs ( $m i R-125 b-5 p$ and $m i R-140-5 p$ ) binding sites in the $3^{\prime}$-UTR and without those sequences were prepared. We have described the methods for transfection and dual-luciferase reporter assays in our previous studies $[42,57,58]$. The reagents used in this study are listed in Table S4. 


\subsection{Statistical Analysis}

We performed statistical analyses using JMP Pro 15 (SAS Institute Inc., Cary, NC, USA). Differences between the two groups were evaluated using Welch's t-test. Dunnett's test was used for multiple group comparisons. A $p$-value less than 0.05 was considered statistically significant.

\section{Conclusions}

This large cohort analysis revealed that high expression of CORO2A in OSCC clinical tissues is highly predictive of a worse prognosis in OSCC patients. The knockdown assays suggested that the expression of $C O R O 2 A$ facilitates cancer cell malignant transformation, e.g., cell proliferation, migration, and invasion. Tumor-suppressive $m i R-125-5 p$ and $m i R-$ 140-5p directly regulate CORO2A expression in OSCC cells. CORO2A- and CORO2Amediated oncogenic signaling pathways may provide novel information regarding OSCC molecular pathogenesis.

Supplementary Materials: The following are available online at https: / www.mdpi.com/article / $10.3390 /$ ijms222312684/s1.

Author Contributions: Data curation, I.K.-K. and S.A.; formal analysis, I.K.-K. and C.M.; investigation, K.T. and A.K. (Ayaka Koma), S.A., C.M. and S.O.; project administration, N.S.; supervision, T.H. and K.U.; writing — original draft, I.K.-K. and N.S.; writing—review \& editing, A.K. (Atsushi Kasamatsu). All authors have read and agreed to the published version of the manuscript.

Funding: This study was supported by JSPS KAKENHI grant numbers 19H03847, 20H03883, and 21K09577.

Institutional Review Board Statement: The study was conducted according to the Decla ration of Helsinki, and approved by the Bioethics Committee of Chiba University (approval number: 28-65, 10 February 2015)

Informed Consent Statement: Informed consent was obtained from all subjects involved in the study.

Data Availability Statement: Our expression data were deposited in the GEO database (accession number: GSE184991).

Acknowledgments: The results shown here are in part based upon data generated by the TCGA Research Network: https://www.cancer.gov/tcga, (accessed on 10 April 2020).

Conflicts of Interest: The authors declare no conflict of interest.

\section{References}

1. Chen, S.H.; Hsiao, S.Y.; Chang, K.Y.; Chang, J.Y. New Insights into Oral Squamous Cell Carcinoma: From Clinical Aspects to Molecular Tumorigenesis. Int. J. Mol. Sci. 2021, 22, 2252. [CrossRef] [PubMed]

2. Bray, F.; Ferlay, J.; Soerjomataram, I.; Siegel, R.L.; Torre, L.A.; Jemal, A. Global cancer statistics 2018: GLOBOCAN estimates of incidence and mortality worldwide for 36 cancers in 185 countries. CA Cancer J. Clin. 2018, 68, 394-424. [CrossRef] [PubMed]

3. Sha, J.; Bai, Y.; Ngo, H.X.; Okui, T.; Kanno, T. Overview of Evidence-Based Chemotherapy for Oral Cancer: Focus on Drug Resistance Related to the Epithelial-Mesenchymal Transition. Biomolecules 2021, 11, 893. [CrossRef] [PubMed]

4. Oosting, S.F.; Haddad, R.I. Best Practice in Systemic Therapy for Head and Neck Squamous Cell Carcinoma. Front. Oncol. 2019, 9, 815. [CrossRef] [PubMed]

5. Picon, H.; Guddati, A.K. Mechanisms of resistance in head and neck cancer. Am. J. Cancer Res. 2020, 10, $2742-2751$.

6. Chow, L.Q.M. Head and Neck Cancer. N. Engl. J. Med. 2020, 382, 60-72. [CrossRef]

7. Joseph, J.P.; Harishankar, M.K.; Pillai, A.A.; Devi, A. Hypoxia induced EMT: A review on the mechanism of tumor progression and metastasis in OSCC. Oral Oncol. 2018, 80, 23-32. [CrossRef]

8. Johnson, D.E.; Burtness, B.; Leemans, C.R.; Lui, V.W.Y.; Bauman, J.E.; Grandis, J.R. Head and neck squamous cell carcinoma. Nat. Rev. Dis. Primers 2020, 6, 92. [CrossRef]

9. Gross, S.R. Actin binding proteins: Their ups and downs in metastatic life. Cell Adh. Migr. 2013, 7, 199-213. [CrossRef]

10. Frugtniet, B.; Jiang, W.G.; Martin, T.A. Role of the WASP and WAVE family proteins in breast cancer invasion and metastasis. Breast Cancer 2015, 7, 99-109. [CrossRef]

11. Chan, K.T.; Creed, S.J.; Bear, J.E. Unraveling the enigma: Progress towards understanding the coronin family of actin regulators. Trends Cell Biol. 2011, 21, 481-488. [CrossRef] 
12. Rybakin, V.; Clemen, C.S. Coronin proteins as multifunctional regulators of the cytoskeleton and membrane trafficking. Bioessays 2005, 27, 625-632. [CrossRef] [PubMed]

13. Uetrecht, A.C.; Bear, J.E. Coronins: The return of the crown. Trends Cell Biol. 2006, 16, 421-426. [CrossRef]

14. Pieters, J.; Müller, P.; Jayachandran, R. On guard: Coronin proteins in innate and adaptive immunity. Nat. Rev. Immunol. 2013, 13, 510-518. [CrossRef] [PubMed]

15. Xavier, C.P.; Rastetter, R.H.; Blömacher, M.; Stumpf, M.; Himmel, M.; Morgan, R.O.; Fernandez, M.P.; Wang, C.; Osman, A.; Miyata, Y.; et al. Phosphorylation of CRN2 by CK2 regulates F-actin and Arp2/3 interaction and inhibits cell migration. Sci. Rep. 2012, 2, 241. [CrossRef] [PubMed]

16. Dai, X.; Liang, Z.; Liu, L.; Guo, K.; Xu, S.; Wang, H. Silencing of MALAT1 inhibits migration and invasion by sponging miR-1-3p in prostate cancer cells. Mol. Med. Rep. 2019, 20, 3499-3508. [CrossRef]

17. Anfossi, S.; Babayan, A.; Pantel, K.; Calin, G.A. Clinical utility of circulating non-coding RNAs-an update. Nat. Rev. Clin. Oncol. 2018, 15, 541-563. [CrossRef]

18. Ha, M.; Kim, V.N. Regulation of microRNA biogenesis. Nat. Rev. Mol. Cell Biol. 2014, 15, 509-524. [CrossRef]

19. Gebert, L.F.R.; MacRae, I.J. Regulation of microRNA function in animals. Nat. Rev. Mol. Cell Biol. 2019, 20, 21-37. [CrossRef]

20. Lin, S.; Gregory, R.I. MicroRNA biogenesis pathways in cancer. Nat. Rev. Cancer 2015, 15, 321-333. [CrossRef]

21. Rupaimoole, R.; Slack, F.J. MicroRNA therapeutics: Towards a new era for the management of cancer and other diseases. Nat. Rev. Drug Discov. 2017, 16, 203-222. [CrossRef] [PubMed]

22. Noguti, J.; De Moura, C.F.; De Jesus, G.P.; Da Silva, V.H.; Hossaka, T.A.; Oshima, C.T.; Ribeiro, D.A. Metastasis from oral cancer: An overview. Cancer Genom. Proteom. 2012, 9, 329-335.

23. Schaks, M.; Giannone, G.; Rottner, K. Actin dynamics in cell migration. Essays Biochem. 2019, 63, 483-495. [CrossRef]

24. Yilmaz, M.; Christofori, G. EMT, the cytoskeleton, and cancer cell invasion. Cancer Metastasis Rev. 2009, 28, 15-33. [CrossRef] [PubMed]

25. Molinie, N.; Gautreau, A. The Arp2/3 Regulatory System and Its Deregulation in Cancer. Physiol. Rev. 2018, 98, 215-238. [CrossRef]

26. Lamb, M.C.; Tootle, T.L. Fascin in Cell Migration: More Than an Actin Bundling Protein. Biology 2020, 9, 403. [CrossRef] [PubMed]

27. Gunning, P.W.; Hardeman, E.C. Tropomyosins. Curr. Biol. 2017, 27, R8-R13. [CrossRef]

28. Ramos-García, P.; González-Moles, M.; González-Ruiz, L.; Ayén, Á.; Ruiz-Ávila, I.; Navarro-Triviño, F.J.; Gil-Montoya, J.A. An update of knowledge on cortactin as a metastatic driver and potential therapeutic target in oral squamous cell carcinoma. Oral Dis. 2019, 25, 949-971. [CrossRef]

29. Weaver, A.M. Cortactin in tumor invasiveness. Cancer Lett. 2008, 265, 157-166. [CrossRef]

30. Ramos-García, P.; Ruiz-Ávila, I.; Gil-Montoya, J.A.; Ayén, Á.; González-Ruiz, L.; Navarro-Triviño, F.J.; González-Moles, M. Relevance of chromosomal band 11q13 in oral carcinogenesis: An update of current knowledge. Oral Oncol. 2017, 72, 7-16. [CrossRef]

31. Ramos-García, P.; González-Moles, M.; Ayén, Á.; González-Ruiz, L.; Ruiz-Ávila, I.; Gil-Montoya, J.A. Prognostic and clinicopathological significance of CTTN/cortactin alterations in head and neck squamous cell carcinoma: Systematic review and meta-analysis. Head Neck 2019, 41, 1963-1978. [CrossRef]

32. Li, J.; Tian, L.; Jing, Z.; Guo, Z.; Nan, P.; Liu, F.; Zou, S.; Yang, L.; Xie, X.; Zhu, Y.; et al. Cytoplasmic RAD23B interacts with CORO1C to synergistically promote colorectal cancer progression and metastasis. Cancer Lett. 2021, 516, 13-27. [CrossRef]

33. Yang, B.; Wang, S.; Zeng, J.; Zhang, Y.; Ruan, X.; Han, W.; Yin, B.; Yuan, J.; Qiang, B.; Ying, W.; et al. Proteomic screening and identification of microRNA-128 targets in glioma cells. Proteomics 2015, 15, 2602-2617. [CrossRef]

34. Han, S.; Ding, X.; Wang, S.; Xu, L.; Li, W.; Sun, W. miR-133a-3p Regulates Hepatocellular Carcinoma Progression Through Targeting CORO1C. Cancer Manag. Res. 2020, 12, 8685-8693. [CrossRef]

35. Wang, J.; Tsouko, E.; Jonsson, P.; Bergh, J.; Hartman, J.; Aydogdu, E.; Williams, C. miR-206 inhibits cell migration through direct targeting of the actin-binding protein coronin 1C in triple-negative breast cancer. Mol. Oncol. 2014, 8, 1690-1702. [CrossRef]

36. Fujii, K.; Miyata, Y.; Takahashi, I.; Koizumi, H.; Saji, H.; Hoshikawa, M.; Takagi, M.; Nishimura, T.; Nakamura, H. Differential Proteomic Analysis between Small Cell Lung Carcinoma (SCLC) and Pulmonary Carcinoid Tumors Reveals Molecular Signatures for Malignancy in Lung Cancer. Proteom. Clin. Appl. 2018, 12, e1800015. [CrossRef] [PubMed]

37. Cheng, X.; Wang, X.; Wu, Z.; Tan, S.; Zhu, T.; Ding, K. CORO1C expression is associated with poor survival rates in gastric cancer and promotes metastasis in vitro. FEBS Open Bio 2019, 9, 1097-1108. [CrossRef] [PubMed]

38. Wang, Z.; Jia, L.; Sun, Y.; Li, C.; Zhang, L.; Wang, X.; Chen, H. CORO1C is Associated with Poor Prognosis and Promotes Metastasis Through PI3K/AKT Pathway in Colorectal Cancer. Front. Mol. Biosci. 2021, 8, 682594. [CrossRef]

39. Huang, W.; Ghisletti, S.; Saijo, K.; Gandhi, M.; Aouadi, M.; Tesz, G.J.; Zhang, D.X.; Yao, J.; Czech, M.P.; Goode, B.L.; et al. Coronin 2A mediates actin-dependent de-repression of inflammatory response genes. Nature 2011, 470, 414-418. [CrossRef]

40. Rastetter, R.H.; Blömacher, M.; Drebber, U.; Marko, M.; Behrens, J.; Solga, R.; Hojeili, S.; Bhattacharya, K.; Wunderlich, C.M.; Wunderlich, F.T.; et al. Coronin 2A (CRN5) expression is associated with colorectal adenoma-adenocarcinoma sequence and oncogenic signalling. BMC Cancer 2015, 15, 638. [CrossRef] [PubMed]

41. Deng, J.L.; Zhang, H.B.; Zeng, Y.; Xu, Y.H.; Huang, Y.; Wang, G. Effects of CORO2A on Cell Migration and Proliferation and Its Potential Regulatory Network in Breast Cancer. Front. Oncol. 2020, 10, 916. [CrossRef] [PubMed] 
42. Oshima, S.; Asai, S.; Seki, N.; Minemura, C.; Kinoshita, T.; Goto, Y.; Kikkawa, N.; Moriya, S.; Kasamatsu, A.; Hanazawa, T.; et al. Identification of Tumor Suppressive Genes Regulated by miR-31-5p and miR-31-3p in Head and Neck Squamous Cell Carcinoma. Int. J. Mol. Sci. 2021, 22. [CrossRef] [PubMed]

43. Huang, S.P.; Jiang, Y.F.; Yang, L.J.; Yang, J.; Liang, M.T.; Zhou, H.F.; Luo, J.; Yang, D.P.; Mo, W.J.; Chen, G.; et al. Downregulation of miR-125b-5p and Its Prospective Molecular Mechanism in Lung Squamous Cell Carcinoma. Cancer Biother. Radiopharm. 2020. [CrossRef] [PubMed]

44. Li, Y.; Wang, Y.; Fan, H.; Zhang, Z.; Li, N. miR-125b-5p inhibits breast cancer cell proliferation, migration and invasion by targeting KIAA1522. Biochem. Biophys. Res. Commun. 2018, 504, 277-282. [CrossRef] [PubMed]

45. Hua, S.; Quan, Y.; Zhan, M.; Liao, H.; Li, Y.; Lu, L. miR-125b-5p inhibits cell proliferation, migration, and invasion in hepatocellular carcinoma via targeting TXNRD1. Cancer Cell Int. 2019, 19, 203. [CrossRef]

46. Hui, L.; Zhang, J.; Guo, X. MiR-125b-5p suppressed the glycolysis of laryngeal squamous cell carcinoma by down-regulating hexokinase-2. Biomed. Pharmacother. 2018, 103, 1194-1201. [CrossRef]

47. Liu, S.; Chen, Q.; Wang, Y. MiR-125b-5p suppresses the bladder cancer progression via targeting HK2 and suppressing PI3K/AKT pathway. Hum. Cell 2020, 33, 185-194. [CrossRef]

48. Park, G.B.; Jeong, J.Y.; Kim, D. Modified TLR-mediated downregulation of miR-125b-5p enhances CD248 (endosialin)-induced metastasis and drug resistance in colorectal cancer cells. Mol. Carcinog. 2020, 59, 154-167. [CrossRef]

49. Mei, L.L.; Wang, W.J.; Qiu, Y.T.; Xie, X.F.; Bai, J.; Shi, Z.Z. miR-125b-5p functions as a tumor suppressor gene partially by regulating HMGA2 in esophageal squamous cell carcinoma. PLoS ONE 2017, 12, e0185636. [CrossRef]

50. Yang, H.L.; Gao, Y.M.; Zhao, J.A. miR-140-5p inhibits human glioma cell growth and invasion by targeting JAG1. Mol. Med. Rep. 2017, 16, 3634-3640. [CrossRef]

51. Li, J.; Gao, J.; Tian, W.; Li, Y.; Zhang, J. Downregulation of serum miR-140-5p predicts poor prognosis of patients with colorectal cancer. Int. J. Clin. Exp. Pathol. 2017, 10, 9503-9508.

52. Wang, Y.; Huang, Q.; Li, F. miR-140-5p targeted FGF9 and inhibited the cell growth of laryngeal squamous cell carcinoma. Biochem. Cell Biol. 2020, 98, 83-89. [CrossRef]

53. Lan, H.; Chen, W.; He, G.; Yang, S. miR-140-5p inhibits ovarian cancer growth partially by repression of PDGFRA. Biomed. Pharmacother. 2015, 75, 117-122. [CrossRef]

54. Fang, Z.; Yin, S.; Sun, R.; Zhang, S.; Fu, M.; Wu, Y.; Zhang, T.; Khaliq, J.; Li, Y. miR-140-5p suppresses the proliferation, migration and invasion of gastric cancer by regulating YES1. Mol. Cancer 2017, 16, 139. [CrossRef]

55. Jing, P.; Sa, N.; Liu, X.; Liu, X.; Xu, W. MicroR-140-5p suppresses tumor cell migration and invasion by targeting ADAM10mediated Notch1 signaling pathway in hypopharyngeal squamous cell carcinoma. Exp. Mol. Pathol. 2016, 100, 132-138. [CrossRef] [PubMed]

56. Zhao, J.; Bai, X.; Feng, C.; Shang, X.; Xi, Y. Long Non-Coding RNA HCP5 Facilitates Cell Invasion and Epithelial-Mesenchymal Transition In Oral Squamous Cell Carcinoma By miR-140-5p/SOX4 Axis. Cancer Manag. Res. 2019, 11, 10455-10462. [CrossRef] [PubMed]

57. Hozaka, Y.; Seki, N.; Tanaka, T.; Asai, S.; Moriya, S.; Idichi, T.; Wada, M.; Tanoue, K.; Kawasaki, Y.; Mataki, Y.; et al. Molecular Pathogenesis and Regulation of the miR-29-3p-Family: Involvement of ITGA6 and ITGB1 in Intra-Hepatic Cholangiocarcinoma. Cancers 2021, 13, 2804. [CrossRef]

58. Okada, R.; Goto, Y.; Yamada, Y.; Kato, M.; Asai, S.; Moriya, S.; Ichikawa, T.; Seki, N. Regulation of Oncogenic Targets by the Tumor-Suppressive miR-139 Duplex (miR-139-5p and miR-139-3p) in Renal Cell Carcinoma. Biomedicines 2020, 8, 599. [CrossRef] [PubMed]

59. Anaya, J. Linking TCGA survival data to mRNAs, miRNAs, and lncRNAs. Peer J. Comput. Sci. 2016, 2, e67. [CrossRef]

60. Agarwal, V.; Bell, G.W.; Nam, J.W.; Bartel, D.P. Predicting effective microRNA target sites in mammalian mRNAs. eLife $2015,4,5$. [CrossRef] 